\title{
The Xiongnu Agency and Its Political Economy Through the Relation with the Han Dynasty
}

\author{
Haoxiang Hong
}

Changzhou No.1 High School, Changzhou, Jiangsu 213004, China, gnOh2004@gmail.com

\begin{abstract}
The period Han Dynasty (202 BCE-220 AD) is the first unified period of China. As the Han histories reveals, one of the main challenges faced by the Han emperor is the relationship with nomands in the north and west of the Han dynasty (occupying approximately the area of current Xingjiang and Inner Mongolia province), known as the Xiongnu. They use several methods such as annual gifts and he-qin to take control of Xiongnu. In fact it was often Xiongnu that held the upper hand. They obtain resources that are both politically valuable and economically valuable to their society from events like annual gifts and he-qin. Moreover, Xiongnu's military attack on the border is to take advantage of the border market to obtain goods they demand and force the Han Dynasty to sign a treaty that benefits them more.
\end{abstract}

Keywords: Xiongnu, Han dynasty, political economy, he-qin, annual gifts, military.

\section{INTRODUCTION}

Han Histories, a history of China finished in 105, covers the Western Han dynasty from the emperor Gaozu of Han dynasty in 206 BCE to Wang Mang usurped the throne in $23 \mathrm{CE}$. The work was composed by Ban $\mathrm{Gu}$ (32-92 CE), an official historian in the Eastern Han court, with the assistance of his sister Ban Zhao. However, there are some bias in the description of Xiongnu because of the difference in ideology and between Han dynasty and Xiongnu Enpire. Also, the current researches mainly describe Xiongnu as a dependency of the Han dynasty and assume them to be dependent on the Han dynasty on food and luxuries. In the work, we are going to work out what is the political economy of Xiongnu and how the they take their initiative while relating with the Han dynasty.

\section{THE ECONOMIC CONTEXT OF THE XIONGNU SOCIETY}

As we know, Xiongnu lived in the Mongolian Plateau and Altay Mountains. They need to move their herds to find water and pasturage. When it's winter and the temperature is low, the grassland in the Mongolian Plateau is often insufficient to feed their livestock like horses, oxen and sheep. Under this environment, the economic crises frequently happen in the nomandic society because of their living style. Nicola Di Cosmo describes the crisis in his book Ancient China and Its Enemies: severe winter, drought, and epidemic; soil that lack of nutrition because of overgazing. Such situations would reduce the size of the herds, threatening the food supply of the nomadic society and forcing the people to seek better land elsewhere [1]. As a result, they regard raiding the border as a way of obtaining resources to solve the economic crisis. The area which the Xiongnu interact with the Han dynasty was the Yellow River bank with land rich in grains and labour. The Xiongnu raided the border and carry away livestock and labour which would help them to overcome the crisis.

Some historians assumed that nomads depend on China in agriculture That's not true. First of all, archaeological discoveries show that to some degree, agriculture was practiced among the nomads [2]. Also, since the nomands' diet is based on meat and dairy products, the consumption of cereals is minimal [3]. Finally, China wasn't the only source of the cereals that are available to the nomands. They could also obtain grains from Manchuria to the Tarim Basin [4]. Although the leadership of Xiongnu imposed on China a tribute payment that included silk, bullion, and grains, that's just a compliment of other resources.

\subsection{The political culture of Xiongnu and the political logic behind the Xiongnu's raid.}

Si Maqian mentioned the political system of Xiongnu in his work Shi ji, in the Xiongnu political system, every position is divided into "left" and "right" from the kings down to the household administrators [5]." Below the supreme "khan," the twenty-four ta ch'en formed a 
supreme political council [6]. The most important officer command ten thousand horsemen, the least important a few thousand [7].

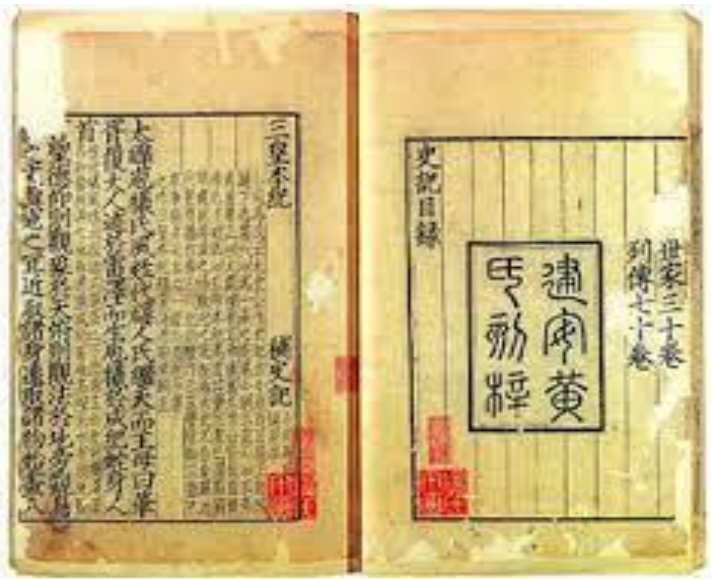

Figure 1 Shi ji by Si Maqian

In nomadic empire like Xiongnu Empire, societies were typically divided into kin groups that shared a common lineage and territory and there are multiple administrators which means the power is distributed [8]. In ancient China, the emperor's commands could be effectively communicated across the emperor. People were loyal to the emperor and the emperor's command would be executed even if some of them are unjust because the emperor has the despotic power. However, in nomadic empires like the Xiongnu empire, there's no centralized hierarchy or political system. In fact, they work through collaboration and are more likely to be a political union and fight for the common goal instead of a totalitarian empire. The building block of the nomadic empire is the militarized worrier elites on horseback. Individual leaders have the capability to make their own decisions. They have their private armies that are loyal to them. It the worrier elites thinks it's not beneficial for him to serve the Xiongnu ruler, he could just leave the empire with his private army. If all the worrier elites leave, the Xiongnu empire collapses. As a consequence, the superior leaders need to have some kind of authorities for their commands to be recognized by inferior leaders. The emperor of the Xiongnu empire needs a rewarding system to persuade the worrier elites to serve for the empire because the nomadic emperor doesn't have such despotic power. The ruler needs constantly create incentive for the warrior leaders to participate in the constitutional project because the emperor couldn't force the warrior to do so.

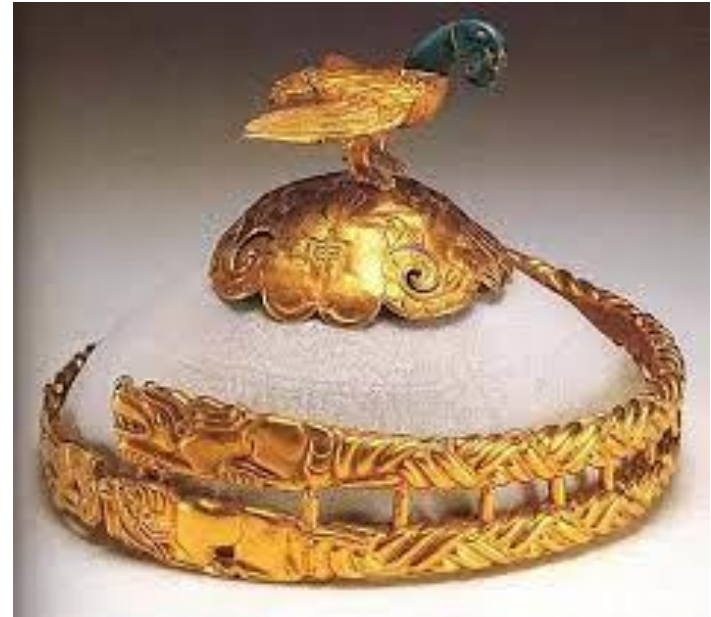

Figure 2 the crown of the Xiongnu emperor

Since the Xiongnu emperor needs to creat a reward system and persuade the warrior leaders to follow him, attacking the Han dynasty and obtain resources like the grains and the luxuries are crucial to the whole political system. First of all, in winter, as the weather is harsh, the individual soldiers couldn't find themselves with enough food to feed their horse, if the Xiongnu elites don't organize sorts of attack to the border, there may be discontent among the soldiers because they couldn't even feed themselves. Thus, there may be disorder among the Xiongnu. Second of all, the Xiongnu elites need to persuade the warrior leaders to serve the empire. On the one hand the warrior leaders could gain some profits from raiding, on the other hand, when the treaty was signed and the luxuries were sent to the Xiongnu elites, the leaders could get some silk and gold for the contribution they made in the war. Since nomands are mobile, they prefer to wear their wealth on their body and regard them as a status marker. Which makes silk and gold stand out from other luxuries. They could wear silk and gold on both their own body and their horse's body. For individual soldiers, most of their wealth is on their body or on their horses. As a result, silk is extremely important in the nomands' political culture. And obtaining silk and gold from the war could be a stimulation for the warrior elites to fight for the empire.

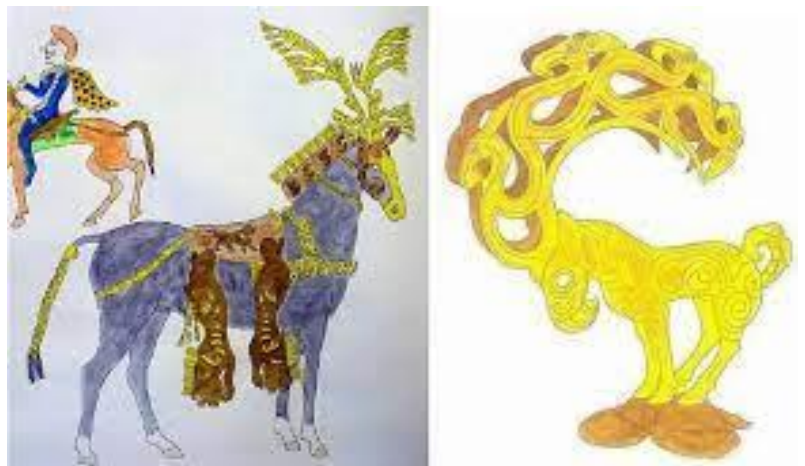

Figure 3 the Xiongnu horse 


\subsection{The military strategies of Xiongnu}

When the Han dynasty had just come into power, Xiongnu attacked the Han dynasty led by Shen-yu Maoutun (209-174 BCE). They surrounded the Han's capital Ma-ye (modern Su-zhou) and the Emperor of the Han was compelled to oppose them in person. After that, Maou-tun pretended to be defeated, tricked the Han troops to follow up and surrounded them for seven days. The Han court was forced to make a treaty with Xiongnu.

Xiongnu chose the opportunity that the Han dynasty was just established and unified China. As a result, the Han court might not have strong military power or economic strength to defend Xiongnu. Also, the Xiongnu leader chose to attack Han dynasty in winter. Twenty to thirty per cent of the Han troops lost the use of their fingers due to the severe frost, rain and snow [9]. Morever, Maou-tun exposed the weak and tricked the Han troop to pursuit them. Then, he surrounded the emperor's party at Pih-tang hill[9]. All these choices made by the Xiongny leader and the tactics they used indicated that Xiongnu wasn't the "Barbarian" outsiders as the Han dynasty always assumed. Instead, they were clever, ambitious and goal-oriented. With such characteristic and a strong military prowess, they succeed in the first attack and took the initiative part of the treaty assigned later.

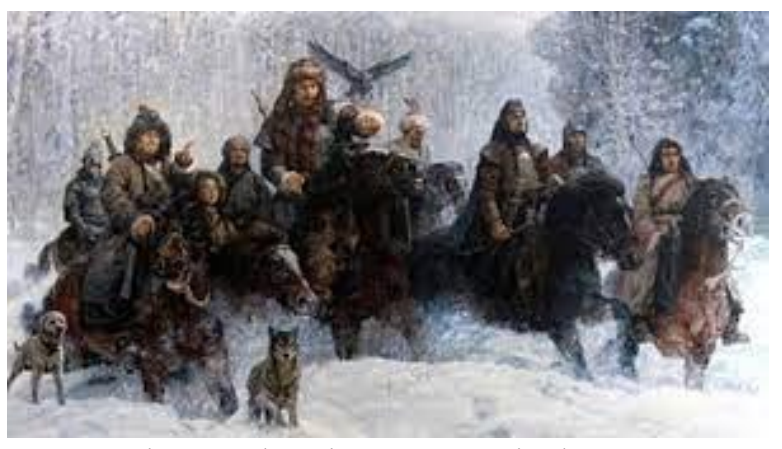

Figure 4 the Xiongnu troop in the snow

What we could inspect from the first war was not only the outstanding military expertise Shen yu has, but also the authority he established among Xiongnu tribes. As we mentioned in the Xiongnu's political culture, the Xiongnu was a political union instead a centralized empire. Achievements of Shen yu largely persuaded the warrior leaders to trust him and conduct his command because he defeated the sedentary country and even forced the emperor of the Han went in person to oppose them. The success also attracted other tribes to join the Xiongnu empire, which would enlarge the empire's territory.

\subsection{The treaty they signed and the luxuries they obtained}

The yearly gifts presented by Han dynasty include raw and wove silk, wine and food[9]. The first treaty signed between Xiongnu and the Han court was recorded in Han Histories. From the context, we can learn that this treaty was signed under the background of the military success of xiong-nu. As a consequence, it's easy to know that they took the initiative part of the negotiation with the Han court. In the treaty, a princess was directed to be the wife of the Xiongnu leader. Additionally, silk, wine and food were sent to Xiongnu annually. The aim of the Han court was to cultivate Chinese tastes among them and introduce a taste for Chinese luxuries [9].

The motivation of the Han court was also recorded in the Han Histories. The entire Hsiung-nu population is less than that of one Chinese province; but the simplicity of their dress and food is one of the important reasons that make them strong, in which they are independent of China. If the Xiongnu wear clothes made by Chinese silk, riding horses among the thorns and brush-wood, their robes and tunics would be unavoidably torn and destroyed; and it is evident that silk garments are not comparable with skin garments for strength and durability. Also, Chinese table delicacies are neither convenient nor wholesome as milk and cream [9].

This is Han's policy to give Xiongnu adapt to chinese culture form. They wanted to cultivate a relation of dependency. However, it's not the political reality, because owning such luxuries was just a symbol of the status of Xiongnu elites among people. Xiongnu elites just use these luxuries in the reward system-- to persuade the warrior leaders to serve the empire. In this aspect, these luxuries are just politically useful, not necessary for the Xiongnu elites. Obviously both Chinese silk garment and Chinese table delicacies are suitable for their lifestyle. As a consequence, there's no dependence of luxuries between Xiongnu and Han dynasty.

Another treaty was signed after a large-scale of raid to the border of the Han dynasty. The emperor of the Han dynasty said in the letter: "I have ordered the proper authorities to transmit yearly to the Shen-yu, a certain amount of grains, gold, silk of the finer and coarser kinds, and other objects [9]." As the nomandic people raided the border frequently, caused great damage to the local residents, the Han court was forced to "buy" the peace with annual gifts like grains, gold, and silk. We could conclude that most of the treaties and annual gifts include these three kinds of goods. Xiongnu elites are clever and goal-oriented. The Han court might regard giving their grains as a measure to cultivate a kind of chinese eating a habit and take control of them. But this couldn't change the Xiongnu's original diet that is based on meat and diary products. We can find these three kinds of goods in almost every treaty. Noble metal like gold can promote trade along and help Xiongnu get contacts with other region [10]. Silk plays the role as the symbol of status and could be utilized in the reward system. These three major kinds of goods obtained from the Han court satisfy 
the demand of the Xiongnu elites, the general public, and the demand for trade and contact with other regions.

\subsection{He-qin policy and its political impact}

The first he-qin was described in the Han Histories. The lady Ung-choo was chosen, and sent to her new lord by Liw King.", "the fraternal bond of peace and amity was renewed" [9]. These contexts show that when the princess was married to the Xiongnu emperor. The Han emperor regards the Xiongnu emperor as counterpart, which is a reminder that how powerful Xiongnu ruler is. Words in some other letters could also prove this: "The great Shen-yu of the Hsiung-nu has transmitted to me a letter"; "If you and I both forget the trifles of the by-gone, and walk together in the broad path, regardless of the evils that are past, uniting the people of the two nations as the children of one family..." [9]. Being regarded as the counterpart of the Han dynasty would contribute a lot to the status of the Xiongnu leader in such political culture. As the Han dynasty was the strongest sedentary country in the world at that time, being regarded as an emperor equal to the emperor of the Han dynasty would be a convincing testimony of the power of the Xiongnu ruler. This would certainly help the Xiongnu emperor to establish an authority among other warrior leaders and attract more tribes to join in.

\section{CONCLUSION}

It is crucial to the survival and the development of the nomadic society all the measures the Xiongnu elites take and all the choices they made are. They raid the border to overcome the economic crisis; they obtain luxuries to maintain the rewarding system to persuade the worriers elites to fight for them; they take advantage of he-qin policy to establish an authority among the worrier elites. The logic behind each of their action was their political culture and economic context and every step they take serves to the stabilization of the whole nomadic society. The nomads like Xiongnu are far beyond the "Barbarian" depicted in the historical records like Han Histories and Shi Ji, instead, they are clever and goal-oriented. As leaders of a nomadic empire, Xiongnu elites take advantage from sedentary country like the not only sustained the survival and the stabilization of the nomadic society, but also extract resources for the development of the whole society. The result of this all these policy of Xiongnu was obvious: Shen-yu Maou-tun took control of over 20 countries to the west of China including Loulan and Wusun. The territory of Xiongnu empire ranged from the south of Yin Shan, to the north of Lake Baikal. Owning over three hundred thousand soldiers, the Xiongnu empire became the strongest countries in the middle asia.

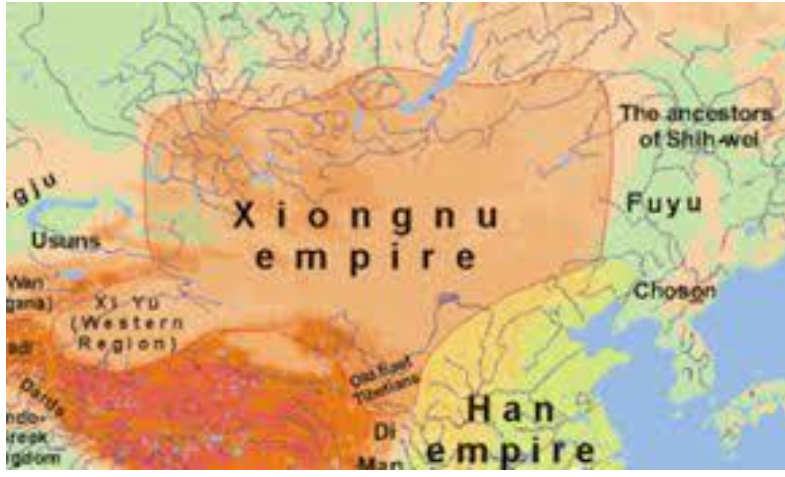

Figure 5 The Xiongnu Empire on the map

\section{REFERENCES}

[1] Nicola Di Cosmo, "Ancient China and its enermies" (Cambridge 2002), part III Those Who Draw the Bow The Rise of the Hsiung-nu Nomadic Empire and the Political Unification of the Nomads, The Formation of the Hsiung-nu State in Historical Perspective, pp. 161-205

[2] Nicola Di Cosmo, "The Economic Basis of the Ancient Inner Asian Nomads and Its Relationship to China," Journal of Asian Studies 53.4 (1994)

[3] N. Shakhanova, "The System of Nourishment among the Eurasian Nomads: The Kazakh Example," in Ecology and Empire. Nomads in the Cultural Evolution of the Old World, ed. Gary Seaman (Los Angeles: Ethnographics /USC, 1989)

[4] S. Minajev, "Les Xiongnu," Dossiers d'Archeologie 212 (April 1996): 74-83; A. P. Davydova and V. P. Shilov, "K voprosy o zemledelii y gunnov," Vestnikdrevnei istorii 2.44 (1983): pp. 193-201.

[5] Si Maqian, "Shi ji”,,(1951, shanghai), chapter180, the biography ot Xiongnu, pp. 2879-2820

[6] Oriens Extremus 1 (1954): 178-202.

[7] Shih chi chu-yi 110, 2318ff.; Shih chi 110, 2890-2.

[8] Lawrence Krader, Social Organization of the Mongol-Turkic Pastoral Nomads (The Hague: Mouton, 1963), pp. 316-72; Elisabeth Bacon, Obok: A Study of Social Structure in Eurasia (New York: Wenner-Gren Foundation, 1958), pp. 106-19.

[9] Daniel C. Waugh, Selection from the Han Narrative Histories(1999), I. Beginnings of Relations with the Hsiung-nu, 2-8, The selection was compiled from Zhang Qian's mission to the West, in the translation by Friedrich Hirth published in the Journal of the American Oriental Society, 37/2 (1917), pp. 93-116.

[10] Gong, H. J. (2020), Why the Conflicts between the Hans and the Hsiung-nu Happened? Advances in Historical Studies, 9, 38-44 